Institute of $\mathbf{F}_{\text {ood and }} \mathbf{A g r i c u l t u r a l}_{\mathbf{S}} \mathbf{S}_{\text {ciences }}$

\title{
Como Realizar un Plan de Gastos - Quinto Paso: Compare sus Ingresos y sus Gastos ${ }^{1}$
}

Nayda I Torres ${ }^{2}$

Ahora que usted ha calculado sus ingresos y sus gastos en los pasos tres y cuatro, compárelos.

Si su ingreso total es más grande que sus gastos totales:

(1) Ingresos Totales

\section{$\$$}

Menos

(2) Gastos Totales

$\$$

(3) Igual

$\$$

Usted puede usar la cantidad sobrante para alcanzar sus metas a corto y largo plazo.
Si sus gastos totales son mayores que sus ingresos totales:

(1) Gastos Totales $\$$ Menos

(2) Ingresos Totales $\$$

(3) Igual $\$$

Será cada vez más difícil alcanzar sus metas a corto o largo plazo si usted continúa aumentando su deuda total todos los meses. Tenga cuidado y ajuste sus gastos porque está gastando más de lo que puede afrontar.

Tanto si usted está ahorrando dinero todos los meses como si está aumentando sus deudas, es probable que pueda manejar su dinero mejor de lo que lo está haciendo ahora.

1. Este documento es la Hojuela FCS7171-Span, una serie del Departamento de Ciencias de la Familia, Juventud y Comunidad, Servicio de Extensión Cooperativa de Florida, Instituto de Alimentos y Ciencias Agrícolas, Universidad de Florida. Fecha de publicación: Octubre 2002. Por favor visite el web de EDIS http://edis.ifas.ufl.edu

2. Escrito por Nayda I. Torres, Profesora, Familia y Economía del Consumidor y la versión en Inglés ha sido revisada por Josephine Turner, CFP, Profesora, Familia y Economía del Consumidor, Servicio de Extensión Cooperativa, Departamento de Ciencias de la Familia, Juventud y Comunidad, Instituto de Alimentos y Ciencias Agrícolas, University of Florida, Gainesville, 32611. Traducido por: Sergio Romero.

El Instituto de Alimentos y Ciencias Agrícolas es un patrono que ofrece igualdad de oportunidad de empleo, autorizado a proveer investigación, información educativa y otros servicios a individuos y a instituciones que ejerzan sus funciones sin tomar en consideración raza, color, sexo, edad, incapacidad o nacionalidad. Para información sobre como obtener otras publicaciones del Servicio de Extensión, comuníquese con la Oficina del Servicio de Extensión Cooperativa de su Condado. Servicio de Extensión Cooperativa de Florida / Instituto de Alimentos y Ciencias Agrícolas / Universidad de Florida, Christine Taylor Waddill, Decano 